\title{
The barriers and strategy of Sota's border tourism area development
}

\section{Kendala dan strategi pengembangan kawasan wisata perbatasan Indonesia- Papua Nugini di Sota Kabupaten Merauke}

\author{
Machya Astuti Dewi \& Iva Rachmawati \\ Department of International Relations, Faculty of Social and Political Sciences, Universitas \\ Pembangunan Nasional "Veteran" Yogyakarta \\ Address: Jl. SWK 104, Sleman, Daerah Istimewa Yogyakarta 55283 \\ E-mail: machya@upnyk.ac.id
}

\begin{abstract}
Merauke, located in the eastern part of Indonesia, has abundant natural resources and tourism potential. Unfortunately, these assets are not enough to establish Merauke as a successful border area. Even though many programs have been created by the local government of Merauke, the management of the border area in Sota Merauke has not been successful. This phenomenon poses a question about the barrier of developing Sota as a border tourism area. The research used qualitative methods by searching for related documents, observing Sota, and interviewing key persons including the local secretary of Merauke, the staff members of the local government of Merauke, the chief of police in Sota, WWF activists, and community leaders in Sota. The research found that the development of Sota as a border tourism area was not running well because of the lack of natural resource management, the lack of qualified human resources, and the lack of infrastructures with many institutional problems in those that did exist. The lack of qualified human resources was the most dominant factor because of the low ethos in the local community focused on developing the border area. The strategies proposed to tackle the barriers are: 1) to generate participation, especially that of youths and women, 2) to encourage tourism-aware groups, 3) to continuously implement group supervision, and 4) to develop border festivals with various cultural attractions and culinary promotions that involve a broad spectrum of Sota people.
\end{abstract}

Keywords: tourism border area; local community; ethos; development

\begin{abstract}
Abstrak
Merauke merupakan kabupaten paling timur Republik Indonesia yang memiliki banyak aset sumber daya alam dan potensi wisata untuk dikembangkan. Sayangnya aset ini belum cukup menjadikan Merauke sebagai wilayah perbatasan yang sukses dalam membangun dirinya. Pengelolaan kawasan perbatasan di distrik Sota yang berbatasan langsung dengan Papua Nugini belum berhasil baik, meskipun berbagai program telah dicanangkan pemerintah daerah Merauke untuk mengembangkan kawasan ini sebagai kawasan wisata. Kondisi tersebut mendorong keingintahuan untuk meneliti kendala apa yang menghambat pengembangan kawasan perbatasan Sota di Merauke. Penelitian dilakukan dengan menggunakan pendekatan kualitatif melalui observasi, penelusuran dokumen, dan wawancara dengan Sekretaris Daerah Merauke, staf Dinas Perindustrian Merauke, Kepala Dinas Kebudayaan Merauke, Kepala Dinas Pariwisata Merauke, Kapolsek Sota, aktivis WWF, dan tokoh masyarakat di Sota. Hasil penelitian menunjukkan bahwa pengembangan kawasan perbatasan Sota di Merauke sebagai daerah wisata terkendala oleh lemahnya pengelolaan sumberdaya alam, kualitas sumberdaya manusia, kurangnya sarana dan prasarana, serta lemahnya aspek kelembagaan. Di antara beberapa penyebab tersebut faktor sumberdaya manusia paling dominan, yaitu kurangnya etos masyarakat lokal dalam membangun daerahnya. Kelemahan ini dapat diatasi dengan strategi: 1) menggerakkan partisipasi masyarakat, 2) mendorong pembentukan kelompok sadar wisata, 3) melakukan pendampingan kelompok secara berkesinambungan, 4) mengembangkan festival perbatasan.
\end{abstract}

Kata kunci: kawasan wisata perbatasan; masyarakat local; etos; pengembangan

\section{Introduction}

The Indonesian government has been paying serious attention to the border area. In order to improve the lives of people who live in the border areas, the policy has shifted from a security approach to a social economic approach. Improving the welfare of the border area was set as priority in 
the Indonesian National Medium Term Development Plan (RPJMN) 2004-2009 and 2010-2014. Border area management is performed through two main approaches. First, is the security approach to enforce nation sovereignty. Second, is the welfare approach by utilizing natural resources.

The research conducted by Raharjo in the Entikong borders, West Borneo (2013: p.73), revealed that the approach shift tended to create positive results. The policy succeeded at solving the problem of slow infrastructure development, trade dependency on Malaysia, the low level of education, threats to nationalism, and badinter-institution coordination. However, the policy series waslacking in its portrayal of the socio-culture situation of the people, thus it generated the probability of ruining the existing social structure. Raharjo added that the government should include local participation when formulating border policies to better realize the common goal of security, welfare, and socio-culture improvement.

Other obstacles, as mentioned by Sholihah (2016:305), were that even though the government has combined the security and welfare aspects, the development process is never a simple matter. Border areas have only limited technology for infrastructure development. Thus, the government needs to employ technology for infrastructure development to improve people's welfare. Unfortunately, the government still has no policy which specifically regulates technology-based infrastructure development, while technology is the aspect that the border area needs the most.

One sector that could be a potential for the border area is tourism. Recently, many areas in Indonesia which share borders with other states have started to develop as a tourist destination object. However, many challenges still need to be addressed, particularly about public participation. For example, Parigi Maoutong area in Central Sulawesi, which shares waters boundaries with the Philippines, keeps improving its tourism sector. One of the most effective methods was by increasing public participation so then the benefits of the development could directly reach the local people. Unfortunately, as seen in many cases in the field, the empowerment program still shows that people have a high level of dependency on government aid (Soedarso, Sutikno, \& Sukardi 2016:159-166).

Tourism area development has been closely associated with the government's role. Nurhidayati (2015:1-10) wrote that the Tourist Village in Batu grew rapidly because the role of local government in supervising tourism product development and market promotion. At first, the government faced many challenges such as the lack of officials with a tourism education background, unattractive product design, a lack of government trust from the local people, and people's limited understanding of tourism. However, great coordination between the stakeholders has greatly contributed to the success of tourist village development in Batu. The role of the local government also plays an essential part in border area tourist village development. In North Borneo, Sudia (2015:498) expressed that the local government hold the responsibility to execute development programs at the local level such as for roads, drainage, bridges, and harbors. Ruhanen (2013) perceived the local government's contribution being in how they promote equality toward access and opportunity to create a transformation. Generally, they also do not have financial problems in the short term. Prokolla's research (2008) showed that the government's role provided positive contributions in the context of funding and tourism sustainability on the Swedish and Finnish borders.

Unfortunately, the role of the local government in promoting a tourist village has not always directly been proportional with the development's success. This difficulty was experienced by Marauke regency, which shares boundaries with Papua New Guinea. As the easternmost point in Indonesia, the government of Merauke appointed the Sota district as being an ecotourism area in 2011. Yet, the program was not implemented well. The area was still far from being founded on nature-based tourism. Instead, there was an unmanaged park with a lack of facilities as the dominant view of the area. The souvenir market, as a supporting tool in the tourist area, was fairly bad managed and the progress of the development was not apparent. As for the consequences, very few tourists visited Sota, even though Sota has abundant natural resource potential. This situation has become a dilemma in border area development efforts. Referring to the Cultural Ecology theory (Steward 1955), humans have a close relation with the environment, but the neglected Sota tourism area shows the contrary, 
especially because the Sota people also have a close relationship with the nature and the woods themselves in particular. Given the background, this research aims to analyze the obstacles that hinder tourist area development in Sota, Merauke, and puts forward possible strategies to overcome the situation.

\section{Research Method}

This research applies qualitative methods through observation and in-depth interviews to reveal the perception of the related parties involved in Merauke's border development. The informants of this research were the government's local secretary, the Head and Staff of Merauke Tourism Department, the Head of Merauke's Department of Culture, the Sota Chief of Police, a World Wide Fund for Nature activist, and Sota public figures. The researchers also gained secondary data about the border area development policy in Merauke from Merauke's Local Secretariat, the Department of Culture of Tourism, the Department of Industry and the Regional Border Management Institute. The secondary data was complemented by primary data from the in-depth interviews with the key figures related to development and observations in the Sota area.

The technique applied to analyze the data was descriptive-qualitative. The data was first categorized and analyzed using the narrative-qualitative method, and this resulted in a description of the border policy in Merauke. We also classified the boundaries that hinder the Merauke-Papua New Guinea area in becoming a leading tourism area.

\section{Results and Discussion}

\section{Border management policy}

Indonesian border management is regulated by the Center of National Strategic Activites (Pusat Kegiatan Strategis Nasional, hereafter referred to as PKSN), which in turn originated from the border policy shifting paradigm going from inward looking to outward looking. An outward looking perspective allows the borders to become a front door for international economic and trade activity. Border management also underwent a transformation by combining a welfare and security approach with an environmental approach (BNPP, 2011-2014). National strategic border areas, as mentioned in Law number (No.) 26 of 2007 about Spatial and Regional Arrangements, are an area whose arrangement is prioritized due to its substantial influence on national sovereignty, security and defense, including its economic and social circumstances, and where the environment has been identified as a world heritage site. PKSN is urban area appointed as an area to support border development.

Government regulation No. 26 of 2008 selected 26 PKSNs with 16 between them being border areas spread over 4 Provinces. 5 areas are located in West Kalimantan, namely Paloh, Jagoibabang, Nangabadau, Entikong, and Jasa. 5 PKSNs are located in East Kalimantan, namely Nunukan, Simanggaris, Long Midang, Long Pahangai, and Long Lawan. 3 are located in Nusa Tenggara Timur, namely Atambua, Kalabahi, and Kefamenanu, and 3 PKSNs are in West Papua, namely Tanah Merah, Merauke, and Arso.

There are eight strategies involved in developing PKSNs with neighboring countries. First, is to accelerate the facilities and infrastructure development to improve the existing capacity. Improvements in the economy and investment require an electrical grid, water, transportation, harbor, market, and more. School and health centers are also urgently needed. Moreover, the government needs to accelerate cross-border posts in locations appointed by both Indonesia and neighboring states. Therefore, border government institutions such as customs, immigration, and security need to be present as well. Secondly, local people's welfare improvement is also needed. Improving the local people's welfare can be done through strengthening their socio-economic condition, improving their income and raising the people's standard of living. The government could facilitate their citizens by providing business centers that are suitable for the geographic terrain and natural resources. Third, is capacity building and human resource empowerment. This strategy aims to enhance the capacity of 
the whole element of the local people, thus they can bring better opportunities. People's empowerment should be in line with the values, norms and culture in society and this requires support from the local people, national and local government, and customary institutions. Fourth, is the local optimization of natural resource utilization. The strategy requires local resources, including human resources, social culture, and natural resources.

The fifth strategy is the selective and gradual development of the center of the border's economic development. Through industry and trade centers, border areas can develop great economic potential. To support this strategy, private sector involvement is essential. In addition, the government should provide fiscal facilities (incentives) or non-fiscal/infrastructure facilities. The sixth factor is the people's resilience, as there is a growing concern that the sense of belonging of people who lives in border areas will shrink because of the ease of various aspects of daily life provided by neighboring countries coming in. Therefore, both the central and local government needs to increase socialization and dissemination about nationalism under the framework of the Republic of Indonesia. The seventh factor is border integrated management, the acceleration of appropriate institutional formations, and the adjustment of management authority. The last factor is boosting regional cooperation in the border area.

One of border areas in Indonesia is Merauke in Papua, which shares direct borders with Papua New Guinea and Australia. Due to its geographical position, Merauke is set as a transit spot for the proliferation of an administrative region in Southern Papua. The proliferated administrative region includes Asmat, Boven Digul, and Mappi. Given the geographical context, economic growth, and area development prospects, Merauke is one of the leading areas in terms of development in Papua. However, the eminence is still not adequate enough to secure people's welfare in the area. The relative growth is not able to create a multiplier effect for the improvement of the economy (Bappeda Kabupaten Merauke 2012)

Merauke has also been appointed as a city to implement PKSN. As a part of the strategy, development was performed in the district of Sota, which is also equipped by PPLB facilities to support economic improvement, particularly trade activities. Border areas also have a large conservation area and come under the protected forest act as the world's lungs. This is not only important to maintain, but it also has economic value if it is developed as a national park, including Wasur National Park.

Wasur National Park is a natural tourism object with a total area of approximately 413.810 hectares. This park is located between Merauke and Sota, and specializes in the conservation of Merauke's endemic species such as deer and cassowary. Aside from the fauna, tourists can also visit the fishing area in the park before they reach the district of Sota. Merauke has 29 tourism objects spread across several districts, consisting of natural tourism, animal conservation areas, border tourism areas, beaches, and religious tourism areas. Buti beach and the border tourism area are considered to be the most attractive destination with the high potential to invites tourists to come. The border tourism area is located in Sota, 76 kilometers from Merauke (Bappeda of Merauke 2012).

\section{Sota's border profile}

Merauke and Papua New Guinea's borders spread for 550 kilometers from Merauke City until Waropko District, covering Merauke, Muting, Mindiptana, and Waropko. These areas are traditional districts with an inadequate amount of border monuments, not to mention their simple shapes as a monument. It is difficult to perform area supervision in the shortcut routes that connect Merauke and Papua New Guinea. Based on the appointed borders posts, Indonesia and Papua New Guinea share borders in:1) Bupul-Lake Murray, 2) Bupul-Aiambak, 3) Erambu-Nakaku, 4) Sota-Morehead, 5) SotaWeam and 6) Kondo-Balamuk (Badan Pengelola Kawasan Perbatasan Kabupaten Keerom 1993).

Out of the 6 borders area, Sota is the only area that is well-managed. However, Sota is not supported by Papua New Guinea because the access to the closest village like Weam, Morehead, and Wereaber consists of land roads that turn extremely muddy when the rain comes. People have to pass two rivers in the dry season and three in the rainy season to cross the border. 
Sota district and Merauke are connected by road with a good paved condition. Public transportation such as buses and mini buses are available for two trips, with it being two hours in duration to reach Merauke from Sota and vice versa. There is also one market at Merauke District markets, schools from kindergarten level through to high school level, sport centers, health centers, the Head of the Village office and prayer facilities. District Sota is inhabited by 17 tribes with various native languages and cultures. The tribes are the following: Marind (Malind), Moraori, Kanum, Yei, Kimaam, Muyu, Mandobo, Jair, Kuruwai, Kombai, Citak, Mitak. Yaghai, Awyu, Asmat, Wiyagar and Yelmek. Marind (Malin) is the only native Merauke tribe. Other than the native people, Merauke is also home to migrants from various ethnicities including those from Java, Borneo, Sulawesi, and Suamtera. The main reasons for migration are job placement, business reasons, migration and marriage. Thus, the population in Merakue is constantly increasing.

Sota's district development is supported by a residential unit focused on local and non-local transmigration, with most of the population running agriculture businesses. Agricultural products are sold in district markets, and some even reach Merauke. Sota has also been appointed as a transit point for people who are traveling to Munting and other districts, and the market has become a place for goods exchange on a daily basis. Basic needs such as food and accommodation positively influence the economic condition in the district. Moreover, the market is located only 300 meters away from the Cross Border Post. A money changer is also available in the market. The near-border location makes Sota a strategic point to rest before one travels to the next district in the north such as Bupul, Muting, Ekobel, Boven Digul and the Bintang Mountains. This creates vigorous market activity in Sota.

Sota is also dense with cross-border activity from Sota to Papua New Guinea, or the opposite route. People who cross Sota's borders are mostly local people originating from Weam, Morehear, and Wereaber districts in Papua New Guinea. Visitors from Papua New Guinea to Merauke number much higher than people who travel from Merauke to Papua New Guinea. In 2016, 30 Indonesian citizens visited Papua New Guinea. The number of Papua New Guinea citizens who crossed into Sota is up to 300 people per month, on average (Sota Pos Immigration 2017).

Two main reasons that motivate Papua New Guinea citizens to visit Sota can be classified into social and economic interests. In the social aspect, they need to visit family members or to continue higher education in Sota. After graduating from Junior High School, kids from Weam and Wereaber often continue their study in Sota Senior High School 1. There were approximately 40 students from Papua New Guinea who went to Sota High School, and who even received Indonesian Government Educational Aid. For economic interest, they need to shop to meet their daily needs. The economic interest was more dominant than the social interest. People shop for the nine basic needs in Sota because it is cheaper for them in Sota than in Papua New Guinea. The distance from their home to Port Moresby is also far, and it can take up to 2 weeks to reach the town. In addition, they do not need passports to cross the Indonesian border. They only need to show a Cross border card to enter Indonesia.

\section{Border tourism area development}

Aware of Sota's strategic potential as a border area, the government of Merauke has developed Sota into a natural-based eco-tourism area. The development and management of Sota refers to Law of Number 10 of 2009 and local government policies to improve people's welfare concerning the aspects of politics, the economy, society, culture, and security. Tourism development aims to provide benefits for both tourists and the host, thus the development is expected to boost the economic condition of the area (Lestari \& Firdausi 2017:262). Moreover, research shows that tourism significantly contributes to an increase in the Gross Domestic Product(Mudrikah et al.2014) and local revenue (Mardianis et al. 2018).

The program was stated in the Government of Merauke Development Vision 2011-2016, "Merauke is a reliable gate of intelligent and healthy human beings, a gate of national food resilience, a gate of welfare and leads to peace of mind". Based on Law Number 10 of 2009, Sota District has four great tourism attraction potentials: 1) natural landscape attraction, 2) history, traditional song, art and culture festivals, 3) the social attractions of the local language and daily life activities, and 4) buildings 
such as monuments and parks. The borders' economic development in Sota was expected to create a multiplier effect for people's empowerment by increasing the revenue for local people and setting Merauke up as an area committed to nature preservation (Badan Perencanaan dan Pembangunan Daerah Kabupaten Merauke 2012).

The former secretary of the government of Merauke, Mike Talubun, stated that Sota possesses great potential when it comes to creating a tourism area. He also added that Sota, which symbolizes Indonesian borders, needs to be highlighted by renovating the existing Merauke Monument. At the same time, Sota is also rich in agricultural product like fruits and vegetables that promotes people's welfare in the area. Mike Talbun stated that:

"Sota has big tourism potential. We have twin monuments, with the one in Sabang, even
though the monuments in Sabang have been rebuild and become much better. We have
already planned to build our monument even though the real zero point is located in the sea.
The border area also has a great tourism potential that could attract many tourists. I believe
that we have to establish a featured product as Sota's specialization. We produce a lot of sweet
potatoes; it is highly unfortunate if people visit Sota and go home with nothing to bring with
them. If we have fruit farms, people would love to come. This could be our icon. Sota is also
a strategic area because it connects Merauke and Boven Digoel, thus eco-tourism will be the
main attraction. If we could have a fruit park like Mekarsari, we can spend time there. I really
wish that Sota had such facilities. Unfortunately, this program finished 3 years ago. I can trust
the issue with the fellows in the Department of Agriculture and the Department of Industry"
(Interview with Mike Talubun, $19^{\text {th }}$ April, 2017).

After three years since its implementation, the Sota eco-tourism program shows no sign of success. The area that supposed to be built into a fruit market has turned into a field with grass and wild bush. The eucalyptus oil distillation activity that was expected to be a program of Sota eco-tourism also did not run well. Up until recently, only one group was left who still actively distilled eucalyptus oil.

Misni, a staff member in Merauke's Department of Industry, shared his experience in supervising the Sota people on the eucalyptus oil distillation program. As an attempt to successful initiate an ecotourism program in Sota, the Department of Industry provided training on eucalyptus oil distillation to the Sota people, because Sota is a rainforest area with a rich eucalyptus leaf resource. However, the Sota people were not really excited about the program.

"Several years ago, the Ministry mandated the eco-tourism program. Now, the program does not run anymore. Only the eucalyptus oil distillation program is conducted on a small scale. The program was initiated by the Directorate General of Regional Autonomy about 4 years ago. We have no idea why, in Sota, the program did not perform well. When the police (Ma'ruf Suroto) managed it, it was nice. There were a lot of trees. But now, nothing is left. People now come to Mr. Ma'ruf's place to go fishing, and they also have fruit farms. That's it, now people only come to Mr Ma'ruf's place (Interview with Misni, 19 ${ }^{\text {th }}$ April, 2017).

Even though only one group left, eucalyptus oil distillation became the only activity still running out of the whole eco-tourism program. Bottles of eucalyptus oil are sold at the border market. Mr. Niko's house was appointed to be the distillation base, involving several relatives. Neighbors in the area purchased oils in liters and packed them into bottles before selling it at the market. Niko explained that he had persuaded the local people to be involved in the distillation activities, but they did not want any part of it for long. The neighbors prefer to seek leaves in the wood and give them to Niko for further processing, reselling the product at the market as gift for tourists who visit Sota's borders. Niko stated that most of his neighbors did not want to be involved in the production chain because they prefer activities that can give them a direct income (Interview with Niko, 17 ${ }^{\text {th }}$ April, 2017).

The culture and work ethic of the Sota people also influences the effort involved in developing the border area. Problems happening in Sota reflect that the central and local government policy of border 
development won't be sufficient unless the local people are aware of the importance of building their area. Aside from the natural potential, the government should also consider the business opportunities available in the field, along with the education background and skills of the local people. Merauke's secretary in the local government, Daniel, expressed his concern regarding the issue.

"I told them that the government will provide seeds, fertilizer, and irrigation. But it was still not enough. We can rely on the woods to make changes. Indeed, they need supervision. In different places, the culture will be different as well. They are not farmers, but hunters. But every day, their hunting area gets narrower. So we try to persuade them to be a farmer. We can develop Sota".

Daniel added that the eco-tourism development in Sota did not succeed because the Sota people were not ready for the transformation, as changing their hunting culture into a farming culture needs patience and tenacity.

"During the three years of the eco-tourism program, groups were formed. In the first year, they were paid to plant trees. In the next year, they should have been already harvested, so government did not need to subsidize them any longer. But the culture grows in people; the receiving money culture. We should pay them to dig holes, and to plant trees. This was originally the government initiative, but they got too used to it. They did not think that in the end, the result was for them, and not for the government. They needed pilot project to be able to move. But once more, they were accustomed to receiving aid, which slowed the ecotourism program development" (interview with Daniel, $18^{\text {th }}$ April, 2017).

The research conducted by the Regional Development Planning Agency of the Government of Merauke revealed that the effort to build Sota as a tourism area has faced many obstacles. In general, the problems are related to natural resource management, human resource quality, economic and people's welfare situation, facilities and infrastructure availability, and the institution's situation. Natural resources are not yet managed in an optimal and sustainable way. The eco-tourism master plan program was planned to be implemented in 3 years (2012-2015). However, after the program ended, there was no follow up initiative to maintain the program's sustainability. In addition, the low quality of human resources makes them unable to manage the natural resources, not to mention that they are slow in receiving new technology and innovations, and they have difficulties in accessing agricultural information. People's inability to portray eco-tourism as a business opportunity also slows eco-tourism developments (Sunarlan \& Kusnadi 2018). The place was also lacking in providing the basic needs of tourism area such as having a social infrastructure, transportation, communication and information facilities. The people's welfare was low, considering the high amount of people who live on the border with Papua New Guinea, many of who live in poverty. In addition, the border surveillance was weak because there was no formal institution with the duty of managing the border area, leading to badly integrated border area management (Badan Perencanaan dan Pembangunan Daerah Kabupaten Merauke 2012).

An informant from Sota Police, L., commented on human resources being a barrier to the eco-tourism program. He stated that it was hard to cooperate with the Sota people, which complicates the people's empowerment attempts. People will scramble for aid. This attitude is different to the migrants in Sota. L. said that in a rural area in Merauke, the people received aid from the government that amounted to 15 Million Rupiah for each association in the neighborhood. However, many times, the head of the neighbor's association moved from one place to other, and yet he was unwilling to step down from his position. Money makes empowerment even more difficult to realize. L. added that it was easier to empower people in route $\mathrm{B}$, the route of the migrants, compared to empowering people in route $\mathrm{A}$, the route of the native people (interview with $\mathrm{L}$, police staff in Sota, 16 ${ }^{\text {th }}$ April, 2017).

However, the Head of Sota Sectoral Police, Ma'ruf Suroto, believes that it is possible to cooperate with and empower the Sota people. Youth associations and housewives in Sota were the most cooperative group. The biggest challenge lies in having the patience to continuously invite local people to grow and adapt to the transformation. Suroto has been long engaged with the Sota people, and expressed his experience: 


\begin{abstract}
"Papua people need time to leave their old culture, [which is] hunting and gathering. Just do not give up. Usually, people who wish for change give up on [the] first attempt. I did not give up on them. I try to understand what they really want; they need supervision and guidance. That's what Papua people need the most" (interview with Ma'ruf Suroto, $21^{\text {st }}$ April, 2017).
\end{abstract}

According to Suroto, approaching local people needs to be conducted very carefully and slowly instead of offering direct programs to people. The direct approach only causes stagnation in the program and the government will run out of funding, yet the people will not change. Therefore, to prompt a discussion forum existing in society, he created the Police and People Cooperation Forum (Forum Kemitraan Polisi dan Masyarakat, hereafter referred to as FKPM). The forum became a form of media for public figures, religious figures, youth figures and women to talk and find solutions to existing problems in society. There was also Polmas, a forum where people could police themselves. The creation of Polmas was important especially if people and local culture projected as the center of economic activity for tourism development. If people-centered development is applied in the tourism industry, local people should be the ones to actively manage and control tourism activity. Their roles are not only limited to being workers, but they also have the right to manage, develop, and gain benefits from their cultural application as a tourism attraction (Junaidi 2017:268).

The effort to build a border area was also implemented by offering entrepreneurship and skill training to local people. Sota people were expected to be able to manage the natural resources, turning them into tourism products with value added for gifts in border areas. The women were trained to make snacks from local commodities such as banana chips. Women became the main target of the development program because they were considered to have great potential in entrepreneurship. The women's empowerment also aimed to develop a culture for the women to lessen their dependence on men (Rustinsyah, 2008: p110). In Merauke, gatherings become the men's main work, which has a low income stability. Unfortunately, the women's empowerment program did not run smoothly because of the difficulties in making reports for the aid program. Low work ethic and inadequate human resources inhibit effective aid utilization (interview with Daniel, $18^{\text {th }}$ April, 2017).

The local government of Merauke has provided incentives such as capital, facilities, and agricultural training, but the program's output is far from the targeted goals. The main reasons for this are because the local culture results in people being accustomed to hunting and gathering instead of growing crops and raising livestock. Day by day, the hunting area is narrowed and this leads to training offered on farming and raising livestock for people. It is unfortunate that the government initiative has not been responded to well by the people.

The lack of people's participation was also expressed by Misni and Koman Sitorus, the staff of Merauke's Department of Industry. The government had planned for there to be a household industry of eucalyptus oil distillation in Sota. The Department of Industry also provided kettles for the area managers to process eucalyptus oil. In fact, only one group is left in the industry. Eucalyptus oil is still packed in used bottles even though the Department of Industry had prepared bottle for packaging for free. Misni also noted:

"We had prepared bottles for packaging purpose, but they never took it. We also provide the label and the bottle cap. After the reform, we could not afford the eucalyptus oil any more, and they did not seem to care" (interview with Misni and Koman Sitorus, 19 ${ }^{\text {th }}$ April, 2017).

Aside from the government, the World Wild Fund (WWF) is also one non-governmental organization involved in Sota's development. They provide routine training on how to pick eucalyptus leaves under the program titled 'Green \& Fair'. According to the WWF coordinator in Sota, the most important things during the supervision are to understand the worker's character. Sota people tend to like the government programs that have cash incentives or direct aid, as expressed by R.

"Sota is a unique area. When government aid is given, the distillation program immediately stops. They prefer to receive cash to making drains or mending the road because the money 
is certain. They prefer the certainty to completing the distillation program. People in southern areas are different to people in the northern areas. Here, we have to behave carefully not to insult them. Once they get insulted, they do not want to hear any explanation. Southern people are easy to influence. If we said A, they will consider it right and follow it. It is easier to influence them because they are typical friendly people, different to the northeast people that tend to be emotional. Yet, the behavior also becomes a challenge because they can easily change their character. Basically, they accept people and policies, but they did not want to follow the program that we give. Our distillation supervision in Gandur, Wasur, Kemerau, Rawa Biru and Sota started in 1997. Native people prefer to pick leaves because the cash is direct. Being involved in production will delay the money because they have to wait for six hours for 1 liter of oil to get the 100.000 Rupiah" (interview with R, 20 ${ }^{\text {th }}$ April, 2017).

Eco-tourism development in Sota has become a good example on how area development faces many challenges due to people's work ethics. To develop an area, the locals need to be completely ready to support development. Infrastructure development and various program initiations have been proven to be insufficient to boost economic growth in the border area. People's participation also determines the success of the programs themselves. According to Beratha (2004:54), empowerment needs to be increased, especially through human resources development to ignite the local willingness to undergo a whole new business chain for their specified product. As stated by Balint in Junaid \& Fauziah (2018: p.19), community capacity will determine the available competency, ability and skills to achieve a particular goal. Therefore, the several strategies available to overcome the issue are: 1) to generate participation especially among youths and women, 2) to encourage tourism-aware groups, 3) to continuously implement group supervision, and 4) to develop border festivals with various cultural attractions and culinary promotion that involves a broad spectrum of the Sota people.

\section{Conclusion}

Human resource contributions have been proven to have a significant effect on border area development. Local people's participation is needed to see an improvement in the border people's welfare. What hinders Sota's development is the lack of participation and support. They lack the awareness to take part in the program fully. Only a limited number of people are actively involved in the programmed activities and effectively utilize the aid given by the government.

A strategy to encourage people's participation is crucial. In the case of Sota, youths and female empowerment could be a proper initiative because they are keen to learn something new. The action taken is expected to boost the tourism potential in Sota, with support from people who are empowerment activists and the local government, who can guide people to promote border area tourism.

\section{References}

Badan Perencanaan Pembangunan Daerah Kabupaten Merauke (2012a) Grand Design Ekonomi Merauke Tahun 2012.

Badan Perencanaan Pembangunan Daerah Kabupaten Merauke (2012b) Grand Design Ekowisata Perbatasan Sota Berbasis Masyarakat.

Badan Pengelola Kawasan Perbatasan Kabupaten Keerom (1993) Ketentuan-Ketentuan Pokok Dalam Pengaturan Khusus Lintas Batas Tradisional dan Kebiasaan.

Beratha IN (2004) Pembangunan Desa Berwawasan Lingkungan. Jakarta: Bumi Aksara.

Daniel (2017) [Personal Communication] 18 April 2017.

Junaidi I (2017) Langkah strategis pengembangan indigenous tourism: Studi kasus di Kabupaten Kepulauan Selayar. Masyarakat, Kebudayaan dan Politik 30 (3):266-277. 
Junaid I \& Fauziah AN (2018) The carrying capacity for the development of marine ecotourism. Masyarakat, Kebudayaan dan Politik 31 (2):230-240.

L (2017) [Personal Communication] 16 April 2017.

Lestari AW \& Firdausi F (2017) Peran Pemerintah Kota Batu dalam implementasi kebijakan pembangunan pariwisata berdasarkan paradigma pembangunan berkelanjutan. Masyarakat, Kebudayaan dan Politik 30 (3):260-265.

Mardianis \& Syartika H (2018) Kontribusi sektor pariwisata terhadap pendapatan asli daerah di Kabupaten Kerinci. Jurnal Ekonomi \& Kebijakan Publik 9 (1):53-65.

Mudrikah A, Sartika D, Yuniarti R, Ismanto, \& Satia AB (2014) Kontribusi sektor pariwisata terhadap GDP Indonesia tahun 2004-2009. Economics Development Analysis Journal 3 (2):362-371.

Misni (2017) [Personal Communication] 19 April 2017.

Nurhidayati SE (2015) Studi evaluasi penerapan Community Based Tourism (CBT) sebagai pendukung agrowisata berkelanjutan. Masyarakat, Kebudayaan dan Politk 8(1);1-10.

R (2017) [Personal Communication] 20 April 2017.

Raharjo SNI (2013) Kebijakan pengelolaan kawasan perbatasan darat Indonesia-Malaysia (Studi Evaluatif di kecamatan Entikong) Widyariset 16 (1):73-80.

Ruhanen L (2013) Local government: Facilitator or inhibitor of sustainable tourism development? Journal of Sustainable Tourism 21 (1):80-98.

Rukin (2018) Economic development as a way to fight against poverty in a coastal society. Masyarakat, Kebudayaan dan Politik 31 (2): 230-240.

Sholihah I (2016) Kebijakan hukum pembangunan kawasan perbatasan melalui infrastruktur berbasis teknologi. Jurnal Rechts Vinding 5 (3):305-321.

Sitorus K (2017) [Personal Communication] 19 April 2017.

Soedarso, Sutikno, \& Sukardi (2016) Strategi pengembangan pariwisata daerah dan pemberdayaan masyarakat di Parigi Moutong. Masyarakat, Kebudayaan dan Politik 29 (3):159-166.

Steward JH (1955) Theory of Culture Change. Urbana: University of Illinois Press.

Sunarlan \& Kusnadi (2018) The synergy of marine fishing and the eco-tourism sector as the solution in resolving poverty of fishermen. Masyarakat, Kebudayaan dan Politik 31 (2):230-240.

Suroto M (2017) [Personal Communication] 21 April 2017.

Talubun M (2017) [Personal Communication] 19 April 2017. 